Proceedings

\title{
Addition of Orange by-products (dry peel) in Orange Jam: Evaluation of Physicochemical Characteristics, Bioactive Compounds and Antioxidant Activity ${ }^{\dagger}$
}

\author{
Vincenzo Sicari ${ }^{1, *}$, Monica Rosa Loizzo ${ }^{2}$, Rosa Romeo ${ }^{1}$, Mariarosaria Leporini ${ }^{2}$, Rosa Tundis ${ }^{2}$ \\ and Marco Poiana ${ }^{1}$ \\ 1 Department of Agraria, University “Mediterranea” of Reggio Calabria, Salita Melissari, 89124 Feo di Vito, \\ Reggio Calabria (RC), Italy; rosa.romeo@unirc.it (R.R.); mpoiana@unirc.it (M.P.) \\ 2 Department of Pharmacy, Health and Nutritional Sciences, University of Calabria, 87036 Arcavacata di \\ Rende (CS), Italy; monica_rosa.loizzo@unical.it (M.R.L.); mariarosarialeporini@virgilio.it (M.L.); \\ rosa.tundis@unical.it (R.T.) \\ * Correspondence: vincenzo.sicari@unirc.it; Tel.: +3909651694370 \\ + Presented at the 1st International e-Conference on Antioxidants in Health and Disease, 01-15 December \\ 2020; Available online: https://cahd2020.sciforum.net/.
}

Published: 30 November 2020

\begin{abstract}
The aim of the present study was to assess the effect of treatment and storage period on the nutritional quality of enriched orange jam during storage for 90 days at $15{ }^{\circ} \mathrm{C}$ and $30{ }^{\circ} \mathrm{C}$. The jam was produced by traditional technique (TP) and with addition of orange peel (OP). All samples were evaluated for $\mathrm{pH}$, total solid soluble, acidity, total phenolic content, total carotenoid content and antioxidant activity(DPPH and ABTS assay). The mean values at T0 of total soluble solids, titratable acidity and $\mathrm{pH}$ of jam samples (TP) were found as $63.03^{\circ} \mathrm{Brix}, 0.60 \%$ and 3.51 respectively. While, the values for OP were $65.11^{\circ} \mathrm{Brix}, 0.61 \%$ and 3.68 respectively. The polyphenols ranged from 83.44 to $126.22 \mathrm{mg} / 100 \mathrm{~g}$ for control samples and from 125.12-171.02 mg/100 g for enriched jam. As regards temperature storage, the enriched jam stored at $15{ }^{\circ} \mathrm{C}$ maintained the better analytical parameters than the samples stored at $30{ }^{\circ} \mathrm{C}$. The results obtained from the experimentation show that use of orange peels in orange jam preserved the functional characteristics during storage.
\end{abstract}

Keywords: citrus by-product; orange jam; bioactive compounds; antioxidant activity

\section{Introduction}

The genus Citrus of the family Rutaceae includes several important fruits such as oranges, mandarins, limes, lemons, sour orange, and grapefruits. Citrus fruits are one of the important crops, with worldwide production of over 80 million tons per year [1].

Citrus fruits are an important source of bioactive compounds. In particular, citrus peels contain significant amounts of phenolic compounds especially phenolic acids and flavonoids [2].

Citrus by-products are secondary product derived from the industrial process of citrus fruits and constitute about $50 \%$ of fresh fruit weight $[3,4]$.

Citrus peel is a very much sought after product in the citrus industry. The most important component of citrus peel is hesperidina, but peel also contains other bioflavonoids, as naringin, 
The 1st International Electronic Conference on Antioxidants in Health and Disease, 1-15 December 2020 diosmin, and neohesperidin. Furthermore, citrus peel contains pectin and has a high vitamin content [5].

A modern industry for the production of citrus derivatives must fully exploit the fruit with the production of all possible derivatives. In the production process of citrus derivatives, such as essence and juice, the peels are a production waste [3].

Orange jam, among other orange derivatives, is a viable alternative to the economic exploitation of fruits, adding value to the fruit and promoting access to its beneficial constituents for the entire year. Adding the orange peel will enhance the flavor of the jam and it will also act as a natural thickening agent.

Considering the large amounts of by-products derived from orange processing, which are generally discarded, the present study aimed to explore the feasibility of using dry (Citrus x sinensis) peel for orange jam production and to evaluate the shelf life of the product.

\section{Experiments}

\subsection{Preparation Orange Jam}

Orange fruits Navel variety were bought from a local market and, after washing the oranges with warm water, to remove all impurities, were manually peeled using a potato peeler, eliminating the albedo and flavedo. The peels were dried in the sun and then ground with a laboratory blender.

Jam was produced according to the traditional method using oranges as a raw material. The formulation consisted of oranges pulp, sugar and pectin.Two types of jam were prepared: one with traditional pectin (TP) and one with orange peel (OP). When the total soluble solids reached $60{ }^{\circ} \mathrm{Brix}$, then the orange peel $(3 \%)$ and commercial pectin were added. Then the mixture was cooked until the total soluble solids reached $67^{\circ}$ Brix.

Both jams were boiled for 30 min before placed in $300 \mathrm{~mL}$ glass jars. Afterwards, the jam jars were pasteurized at $65^{\circ} \mathrm{C}$ for $30 \mathrm{~min}$.

The jams were divided into two groups: one stored at $15^{\circ} \mathrm{C}$, and other at $30^{\circ} \mathrm{C}$. All samples were stored for a total of 90 days. An analytical determination was carried out every 15 days.

\subsection{Chemical Analysis of Orange Jam}

\subsection{1. $\mathrm{pH}$, Acidity and Total Soluble Solids}

The $\mathrm{pH}$ was measured in sample juices by $\mathrm{pH}$ meter (Basic Model 20, Crison) and the total titratable acidity (TA) was assessed by titration with $\mathrm{NaOH}(0.1 \mathrm{~N})$ to $\mathrm{pH} 8.1$ and expressed as citric acid \%. The soluble solids total (SST) in the jam was estimated by a digital refractometer PR-201 $\alpha$ (Atago, Tokyo, Japan) and expressed as ${ }^{\circ}$ Brix at $20^{\circ} \mathrm{C}$.

\subsubsection{Total Phenolic and Carotenoid Content}

The total phenolic content of Citrus fruit juices was determined by the Folin-Ciocalteu method [6] [22]. An aliquot of $500 \mu \mathrm{L}$ of juice was mixed with $1 \mathrm{ml}$ of Folin-Ciocalteu reagent and $10 \mathrm{~mL}$ of $20 \% \mathrm{Na}_{2} \mathrm{CO}_{3}$. The absorbance was measured at $\lambda=760 \mathrm{~nm}$ using a UV-Vis Agilent 8453 spectrophotometer (Agilent Technologies, Italy) after $2 \mathrm{~h}$ in the dark. The results were expressed as gallic acid equivalents (GAE) in $\mathrm{mg} / 100 \mathrm{~mL}$.

The total carotenoid content (TCC) was determined as previously described [7]. Briefly, extract was added to $\mathrm{NaCl} 5 \%$ solution, vortexed for $30 \mathrm{~s}$ and centrifuged at $4500 \mathrm{rpm}$ for 10 min. The supernatant $(100 \mu \mathrm{L})$ was diluted with $0.9 \mathrm{~mL}$ of $\mathrm{n}$-hexane and measured at $460 \mathrm{~nm}$. TCC was expressed as mg $\beta$ carotene equivalents/g FW.

\subsubsection{Antioxidant Activity}


The 1st International Electronic Conference on Antioxidants in Health and Disease, 1-15 December 2020

The antioxidant activity was determined using DPPH free radical assay [8]. An aliquot of $2.5 \mathrm{~mL}$ of $0.06 \mathrm{mM}$ DPPH methanolic solution was added to $50 \mu \mathrm{L}$ of orange jam. The absorbances at $\mathrm{t} 0$ and t5 were measured at $\lambda=515 \mathrm{~nm}$ using a UV-Vis Agilent 8453 spectrophotometer (Agilent Technologies, Italy). The results were expressed according the following equation:

$(\%)$ Inhibition $=(1-\mathrm{Af} / \mathrm{A} 0) \times 100$

where Af $=$ absorbance DPPH fruit juice at $\mathrm{t}=5 \mathrm{~min}$ and $\mathrm{A} 0=\mathrm{absorbance} \mathrm{DPPH}(\mathrm{control})$ at $\mathrm{t}=$ $0 \mathrm{~min}$. All tests were run in triplicate and the results expressed as means \pm standard deviation (SD). Trolox was used as a standard antioxidant and juice activity was expressed in $\mathrm{mM}$ of Trolox equivalents.

\section{ABTS}

The radical scavenging capacity of the samples for the ABTS (2,2'-azinobis-3ethylbenzothiazoline-6-sulfonate) radical cation was determined as described by $\operatorname{Re}$ et al. [9]. ABTS was generated by mixing $7 \mathrm{mM}$ of $\mathrm{ABTS}$ and $\mathrm{K}_{2} \mathrm{~S}_{2} \mathrm{O}_{8}$ (potassium persulfate) $140 \mathrm{mM}$. followed by storage in the dark at room temperature for $16 \mathrm{~h}$ before use. The mixture was diluted (1:80) with ethanol to give an absorbance at $734 \mathrm{~nm}$ using the spectrophotometer. Each sample was diluted with $100 \mu \mathrm{L}$ of was allowed to react with fresh ABTS solution $(900 \mu \mathrm{L})$, and then the absorbance was measured 6 min after initial mixing. All measurements were performed in triplicate.

\section{Statistical Analysis}

All the experiments were conducted in triplicate, and the results were given as mean value \pm standard deviation. Analysis of variance was performed by ANOVA and the difference between the means were analysed using Tukey test.

\section{Results}

The $\mathrm{pH}$ value is significant indicator factor to obtain optimum gel condition. Table 1 shows the changes in $\mathrm{pH}$ values for jam prepared with traditional pectin (TP) and orange peel (OP) during storage at the two different temperatures

Changes in $\mathrm{Ph}$ values of $\mathrm{pH}$ for $\mathrm{TP}$ and $\mathrm{OP}$ at different temperatures during storage are presented inTable 1 . It can be said that $\mathrm{pH}$ values decreased significantly $(p<0.01)$ during storage regardless of storage temperature. The samples added with orange peel shown a ph values ranged from 3.61 and 3.41. In contrast the traditional jam shown a highest ph values ranged from 3.68 and 3.51 at the end of storage.

Table 1. $\mathrm{pH}$ of orange jam during storage at different temperature.

\begin{tabular}{|c|c|c|c|c|c|c|c|c|}
\hline \multicolumn{9}{|c|}{ Time Storage (Days) } \\
\hline & 0 & 15 & 30 & 45 & 60 & 75 & 90 & $\begin{array}{c}\text { Sign } \\
.\end{array}$ \\
\hline $\mathrm{TP} 15^{\circ} \mathrm{C}$ & $\begin{array}{lll}3.51 & \pm & \pm .71 \\
& \text { сA } & \end{array}$ & $\begin{array}{c}3.41 \pm 1.02 \\
\mathrm{cD}\end{array}$ & $\begin{array}{c}3.45 \pm 0.24 \\
\text { cc }\end{array}$ & $3.48 \pm 0.11 \mathrm{cB}$ & $\begin{array}{c}3.51 \pm 0.63 \\
\text { aA }\end{array}$ & $3.50 \pm 0.44 \mathrm{cAB}$ & $\begin{array}{l}3.4 \\
2 \pm \\
0.3 \\
6 \mathrm{bD}\end{array}$ & $* *$ \\
\hline $\begin{array}{l}\text { OP } 15 \\
{ }^{\circ} \mathrm{C}\end{array}$ & $3.68 \pm 0.11 \mathrm{aA}$ & $\begin{array}{c}3.59 \pm 1.44 \\
\mathrm{aB}\end{array}$ & $\begin{array}{c}3.51 \pm 0.62 \\
b c\end{array}$ & $3.56 \pm 0.20 \mathrm{aB}$ & $\begin{array}{c}3.53 \pm 0.58 \\
\mathrm{aB}\end{array}$ & $3.53 \pm 0.67 \mathrm{abB}$ & $\begin{array}{c}3.4 \\
9 \pm \\
0.5 \\
7 \mathrm{aC}\end{array}$ & $* *$ \\
\hline $\mathrm{TP} 30^{\circ} \mathrm{C}$ & $3.61 \pm 0.23 \mathrm{bA}$ & $\begin{array}{c}3.49 \pm 0.98 \\
\text { bB }\end{array}$ & $\begin{array}{c}3.42 \pm 0.49 \\
\mathrm{dE}\end{array}$ & $\begin{array}{c}3.51 \pm 0.52 \\
\text { bBC }\end{array}$ & $\begin{array}{c}3.52 \pm 0.67 \\
\mathrm{aD}\end{array}$ & $\begin{array}{c}3.51 \pm 0.83 \\
\text { bcCD }\end{array}$ & $\begin{array}{l}3.4 \\
1 \pm \\
0.7 \\
7 \mathrm{bE}\end{array}$ & $* *$ \\
\hline $\begin{array}{c}\mathrm{OP} 30 \\
{ }^{\circ} \mathrm{C}\end{array}$ & $3.68 \pm 0.27 \mathrm{aA}$ & $\begin{array}{c}3.61 \pm 0.77 \\
\mathrm{aB}\end{array}$ & $\begin{array}{c}3.58 \pm 0.82 \\
\mathrm{aC}\end{array}$ & $\begin{array}{c}3.57 \pm 0.37 \\
\mathrm{aCD}\end{array}$ & $\begin{array}{c}3.54 \pm 0.43 \\
\mathrm{aE}\end{array}$ & $3.55 \pm 0.81 \mathrm{aDE}$ & $\begin{array}{l}3.5 \\
1 \pm \\
0.8 \\
2 \mathrm{aF}\end{array}$ & $* *$ \\
\hline
\end{tabular}


Data are presented as means \pm standard deviations. Means followed by different capital letters in a row and different lowercase letters in a column are significantly different by Tukey HSDa test. ${ }^{* *}$ Significance at $p<0.01$.

As can be seen in Figure 1, the addition of orange peel to jam affected the content of TSS. In particular, TSS values examination ranged from $63.03-63.55{ }^{\circ}$ Brix for TP at $15^{\circ} \mathrm{C}$ and $63.03-64.89$ ${ }^{\circ}$ Brix at $30{ }^{\circ} \mathrm{C}$. While, TSS values fluctuated from $65.11-65.23{ }^{\circ}$ Brix for OP at $15{ }^{\circ} \mathrm{C}$ and $65.11-66.33$ ${ }^{\circ}$ Brix at $30{ }^{\circ} \mathrm{C}$.

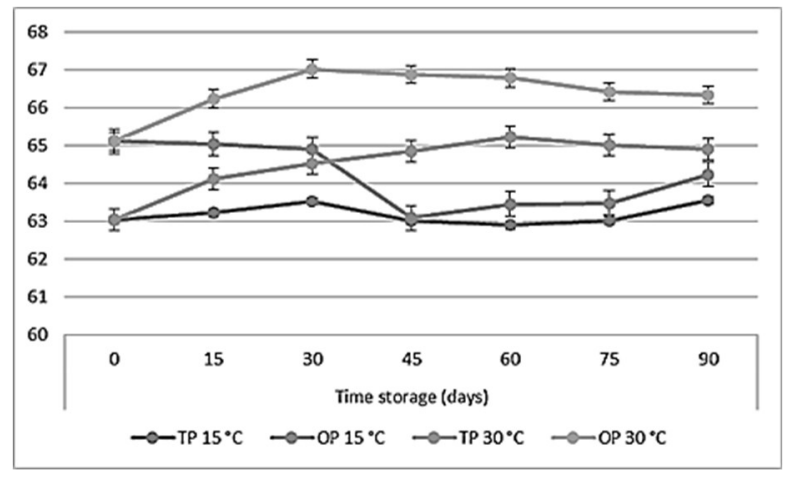

Figure 1. Total solid soluble (TSS) of orange jam during storage at different temperature.

According to $\mathrm{Ph}$ values, all samples shown an increase of $\mathrm{Ph}$ values during storage (Table 3). The acidity (TA) value of jam achieved higher value $(0.70 \%)$, while jam had lower value $(0.60 \%)$.

Table 3. Titratable acidity $(\mathrm{g} / 100 \mathrm{~g}$ acid citric) of orange jam during storage at different temperature.

\begin{tabular}{|c|c|c|c|c|c|c|c|c|}
\hline \multicolumn{9}{|c|}{ Time Storage (Days) } \\
\hline & 0 & 15 & 30 & 45 & 60 & 75 & 90 & $\begin{array}{c}\text { Sig } \\
\text { n. }\end{array}$ \\
\hline $\begin{array}{c}\text { TP } 15 \\
{ }^{\circ} \mathrm{C}\end{array}$ & $\begin{array}{l}0.60 \pm \\
0.02 \mathrm{ac}\end{array}$ & $\begin{array}{c}0.71 \pm 0.04 \\
\mathrm{cAB}\end{array}$ & $\begin{array}{c}0.72 \pm 0.04 \\
\mathrm{CAB}\end{array}$ & $\begin{array}{c}0.71 \pm 0.01 \\
\text { bAB }\end{array}$ & $\begin{array}{c}0.68 \pm 0.04 \\
\mathrm{bAB}\end{array}$ & $\begin{array}{c}0.75 \pm 0.03 \\
\text { aA }\end{array}$ & $\begin{array}{c}0.6 \\
3 \pm \\
0.0 \\
2 \\
\text { bBC }\end{array}$ & $* *$ \\
\hline $\begin{array}{l}\text { OP } 15 \\
{ }^{\circ} \mathrm{C}\end{array}$ & $\begin{array}{l}0.61 \pm \\
0.02 \mathrm{aE}\end{array}$ & $\begin{array}{c}0.78 \pm 0.02 \\
\text { aA }\end{array}$ & $\begin{array}{c}0.75 \pm 0.03 \\
\text { bB }\end{array}$ & $\begin{array}{c}0.75 \pm 0.01 \\
\mathrm{aB}\end{array}$ & $\begin{array}{c}0.71 \pm 0.02 \\
\mathrm{abC}\end{array}$ & $\begin{array}{c}0.73 \pm 0.01 \\
\mathrm{aBC}\end{array}$ & $\begin{array}{c}0.6 \\
6 \pm \\
0.0 \\
1 \\
\mathrm{aD}\end{array}$ & $* *$ \\
\hline $\begin{array}{c}\text { TP } 30 \\
{ }^{\circ} \mathrm{C}\end{array}$ & $\begin{array}{l}0.60 \pm \\
0.03 \mathrm{aD}\end{array}$ & $\begin{array}{c}0.75 \pm 0.01 \\
\text { bA }\end{array}$ & $\begin{array}{c}0.73 \pm 0.02 \\
\text { bcA }\end{array}$ & $\begin{array}{c}0.75 \pm 0.02 \\
\text { aA }\end{array}$ & $\begin{array}{c}0.72 \pm 0.02 \\
\text { aA }\end{array}$ & $\begin{array}{c}0.69 \pm 0.01 \\
b B\end{array}$ & $\begin{array}{c}0.6 \\
5 \pm \\
0.0 \\
2 \\
a b C\end{array}$ & $* *$ \\
\hline $\begin{array}{c}\text { OP } 30 \\
{ }^{\circ} \mathrm{C}\end{array}$ & $\begin{array}{l}0.61 \pm \\
0.05 \mathrm{aF}\end{array}$ & $\begin{array}{c}0.77 \pm 0.04 \\
\text { abB }\end{array}$ & $\begin{array}{c}0.80 \pm 0.06 \\
\text { aA }\end{array}$ & $\begin{array}{c}0.74 \pm 0.03 \\
\mathrm{ac}\end{array}$ & $\begin{array}{c}0.70 \pm 0.02 \\
b D\end{array}$ & $\begin{array}{c}0.67 \pm 0.06 \\
b \mathrm{bE}\end{array}$ & $\begin{array}{c}0.6 \\
6 \pm \\
0.0 \\
2 \\
\mathrm{aE}\end{array}$ & ** \\
\hline Sign. & ns & $* *$ & $* *$ & * & $*$ & * & $*$ & \\
\hline
\end{tabular}


The 1st International Electronic Conference on Antioxidants in Health and Disease, 1-15 December 2020

Data are presented as means \pm standard deviations. Means followed by different capital letters in a row and different lowercase letters in a column are significantly different by Tukey HSDa test. ** Significance at $p<0.01$.

The change in total polyphenols values after treatments and during storage is reported in Table 4. Total polyphenol content at T0 was $83.44 \mathrm{mg} / 100 \mathrm{~g}$ and $125.12 \mathrm{mg} / 100 \mathrm{~g}$ for jam TP and OP, respectively. At the end of storage (90 days), the samples added with orange peel shown the best results in terms of plyphenols contents regardless of storage temperature

The effect of storage on the total carotenoid content is shown in Table 5.Before storage were 2.12 $\mu \mathrm{g} / \mathrm{g}$ and $3.48 \mu \mathrm{g} / \mathrm{g}$ for TP and OP, respectively. The total carotenoids showed a declining trend for all stored samples. The concentration of total carotenoids decreased by $1.14 \mu \mathrm{g} / \mathrm{g}$ and $1.03 \mu \mathrm{g} / \mathrm{g}$, respectively when orange jam (TP) was stored at $15^{\circ} \mathrm{C}$ and $30^{\circ} \mathrm{C}$ for 90 days. While, the concentration decresed by $2.42 \mu \mathrm{g} / \mathrm{g}$ and $1.77 \mu \mathrm{g} / \mathrm{g}$, respectively when OP samples was stored at $15^{\circ} \mathrm{C}$ and $30{ }^{\circ} \mathrm{C}$ for 90 days.

Table 4. Total polyphenol content (mg GAE/100 g) in orange jam with different temperatures and time storage.

\begin{tabular}{|c|c|c|c|c|c|c|c|c|}
\hline \multicolumn{9}{|c|}{ Time Storage (Days) } \\
\hline & 0 & 15 & 30 & 45 & 60 & 75 & 90 & $\begin{array}{c}\text { Sig } \\
\text { n. }\end{array}$ \\
\hline $\begin{array}{c}\mathrm{TP} 15 \\
{ }^{\circ} \mathrm{C}\end{array}$ & $\begin{array}{c}83.44 \pm \\
2.98 \text { bB }\end{array}$ & $\begin{array}{c}124.04 \pm \\
3.85 \mathrm{cA}\end{array}$ & $\begin{array}{c}78.44 \pm \\
6.85 \mathrm{cC}\end{array}$ & $\begin{array}{l}67.82 \pm \\
4.63^{b D}\end{array}$ & $\begin{array}{c}55.23 \pm \\
5.02 \mathrm{dE}\end{array}$ & $\begin{array}{c}49.25 \pm \\
3.02 \mathrm{dF}\end{array}$ & $\begin{array}{c}51 \\
03 \\
\pm \\
3.1 \\
2 \mathrm{dF}\end{array}$ & $* *$ \\
\hline $\begin{array}{l}\text { OP } 15 \\
{ }^{\circ} \mathrm{C}\end{array}$ & $\begin{array}{c}125.12 \pm \\
3.41 \mathrm{aB}\end{array}$ & $\begin{array}{c}170.14 \pm \\
3.56 \mathrm{aA}\end{array}$ & $\begin{array}{c}105.41 \pm \\
7.23 \mathrm{ac}\end{array}$ & $\begin{array}{l}92.56 \pm \\
6.45 \mathrm{aD}\end{array}$ & $\begin{array}{c}80.23 \pm \\
6.12 \mathrm{aE}\end{array}$ & $\begin{array}{c}77.45 \pm \\
5.23 \mathrm{aF}\end{array}$ & $\begin{array}{c}72 . \\
14 \\
\pm \\
4.5 \\
1 \mathrm{aG} \\
\end{array}$ & $* *$ \\
\hline $\begin{array}{c}\mathrm{TP} 30 \\
{ }^{\circ} \mathrm{C}\end{array}$ & $\begin{array}{c}83.44 \pm \\
4.22 \mathrm{bB}\end{array}$ & $\begin{array}{c}126.22 \pm \\
5.23 \mathrm{bA}\end{array}$ & $\begin{array}{c}85.08 \pm \\
5.41^{\mathrm{bB}}\end{array}$ & $\begin{array}{l}68.12 \pm \\
3.82 \mathrm{bC}\end{array}$ & $\begin{array}{c}61.25 \pm \\
6.12 \mathrm{cE}\end{array}$ & $\begin{array}{l}64.23 \pm \\
3.94 \mathrm{cD}\end{array}$ & $\begin{array}{c}59 \\
23 \\
\pm \\
6.0 \\
2 \mathrm{cE}\end{array}$ & $* *$ \\
\hline $\begin{array}{l}\mathrm{OP} 30 \\
{ }^{\circ} \mathrm{C}\end{array}$ & $\begin{array}{c}125.12 \pm \\
3.83 \mathrm{aB}\end{array}$ & $\begin{array}{c}171.02 \pm \\
4.03 \mathrm{aA}\end{array}$ & $\begin{array}{c}107.84 \pm \\
7.12 \mathrm{aC}\end{array}$ & $\begin{array}{c}66.45 \pm \\
2.45 \mathrm{bE}\end{array}$ & $\begin{array}{l}70.03 \pm \\
4.56 \text { bD }\end{array}$ & $\begin{array}{l}71.25 \pm \\
3.52 \mathrm{bD}\end{array}$ & $\begin{array}{c}64 . \\
23 \\
\pm \\
4.8 \\
5 \mathrm{bE}\end{array}$ & $* *$ \\
\hline Sign. & $* *$ & $* *$ & $* *$ & $* *$ & $* *$ & $* *$ & $* *$ & \\
\hline
\end{tabular}

Data are presented as means \pm standard deviations. Means followed by different capital letters in a row and different lowercase letters in a column are significantly different by Tukey HSDa test. ** Significance at $p<0.01$.

Table 5. Carotenoid content $(\mu \mathrm{g} / \mathrm{g})$ in orange jam during storage at different temperatures.

\begin{tabular}{|c|c|c|c|c|c|c|c|c|}
\hline \multicolumn{9}{|c|}{ Time Storage (Days) } \\
\hline & 0 & 15 & 30 & 45 & 60 & 75 & 90 & $\begin{array}{c}\text { Sig } \\
\text { n. }\end{array}$ \\
\hline TP 15 & $2.12 \pm$ & $2.61 \pm$ & $1.91 \pm 0.37$ & $1.57 \pm 0.17$ & $1,35 \pm$ & $1.22 \pm 0.10$ & 1.1 & $* *$ \\
\hline${ }^{\circ} \mathrm{C}$ & $0.218^{\mathrm{bB}}$ & $0.46 \mathrm{cA}$ & $\mathrm{cC}$ & $\mathrm{dD}$ & $0.11^{\mathrm{cE}}$ & $\mathrm{dF}$ & $4 \pm$ & . \\
\hline
\end{tabular}




\begin{tabular}{|c|c|c|c|c|c|c|c|c|}
\hline & & & & & & & $\begin{array}{c}0.2 \\
\mathrm{cG}\end{array}$ & \\
\hline $\begin{array}{c}\text { OP } 15 \\
{ }^{\circ} \mathrm{C}\end{array}$ & $\begin{array}{c}3.48 \pm 0.31 \\
\mathrm{aA}\end{array}$ & $\begin{array}{l}3.15 \pm \\
0.51 \mathrm{aA}\end{array}$ & $\begin{array}{c}3.03 \pm 0.21 \\
\mathrm{aAB}\end{array}$ & $\begin{array}{c}2.88 \pm 0.31 \\
\mathrm{bAB}\end{array}$ & $\begin{array}{l}2.44 \pm \\
0.37 \mathrm{aB}\end{array}$ & $\begin{array}{c}2.75 \pm 0.42 \\
\text { аАв }\end{array}$ & $\begin{array}{c}2.4 \\
2 \pm \\
0.3 \\
1 \\
\mathrm{aB}\end{array}$ & ** \\
\hline $\begin{array}{c}\text { TP } 30 \\
{ }^{\circ} \mathrm{C}\end{array}$ & $\begin{array}{c}2.12 \pm 0.36 \\
b B\end{array}$ & $\begin{array}{l}3.12 \pm \\
0.42 \text { bA }\end{array}$ & $\begin{array}{c}2.12 \pm 0.22 \\
b B\end{array}$ & $\begin{array}{c}2.03 \pm 0.12 \\
\mathrm{cC}\end{array}$ & $\begin{array}{c}1.74 \pm \\
0.11 \text { bD }\end{array}$ & $\begin{array}{c}1.47 \pm 0.14 \\
\mathrm{cE}\end{array}$ & $\begin{array}{c}1.0 \\
3 \pm \\
0.0 \\
8 \\
\mathrm{dF}\end{array}$ & $* *$ \\
\hline $\begin{array}{c}\text { OP } 30 \\
{ }^{\circ} \mathrm{C}\end{array}$ & $\begin{array}{c}3.48 \pm 0.42 \\
\text { aA }\end{array}$ & $\begin{array}{l}3.12 \pm \\
0.46 \mathrm{bB}\end{array}$ & $\begin{array}{c}3.03 \pm 0.52 \\
\mathrm{aC}\end{array}$ & $\begin{array}{c}3.01 \pm 0.26 \\
\mathrm{aC}\end{array}$ & $\begin{array}{l}2.44 \pm \\
0.75 \mathrm{aD}\end{array}$ & $\begin{array}{c}1.89 \pm 0.25 \\
b E\end{array}$ & $\begin{array}{c}1.7 \\
7 \pm \\
0.6 \\
3 \\
\text { bF }\end{array}$ & $* *$ \\
\hline Sign. & ** & $* *$ & ** & $* *$ & $* *$ & $* *$ & ** & \\
\hline
\end{tabular}

Data are presented as means \pm standard deviations. Means followed by different capital letters in a row and different lowercase letters in a column are significantly different by Tukey HSDa test. ${ }^{* *}$ Significance at $p<0.01$.

The antioxidant activity of jam prepared with traditional pectin (TP) and orange peel (OP) was investigated.

In DPPH assay (Figure 2), the jam prepared with traditional pectin (TP) showed values ranging from 94.21 to $33.02(\% \mathrm{I})$ at $15^{\circ} \mathrm{C}$ and 94.21 to 22.45 at $30^{\circ} \mathrm{C}$. In particular, it was observed that during storage of jams to reduce antioxidant capacity. The same trend was observed for jams prepared with addition orange peel (OP). In fact, values ranging from 119.06 to 48.03 (\% I) at $15{ }^{\circ} \mathrm{C}$ and 119.06 to 31.56 at $30^{\circ} \mathrm{C}$.

In both cases, the jam stored at $15^{\circ} \mathrm{C}$ showed a higher antioxidant activity and among the latter, the jam prepared with the addition of orange peels had the highest value (Figure 2).

The same trend observed was observed with the ABTS test (Figure 3). In particular, an increase was observed for the first 60 days then decreased.

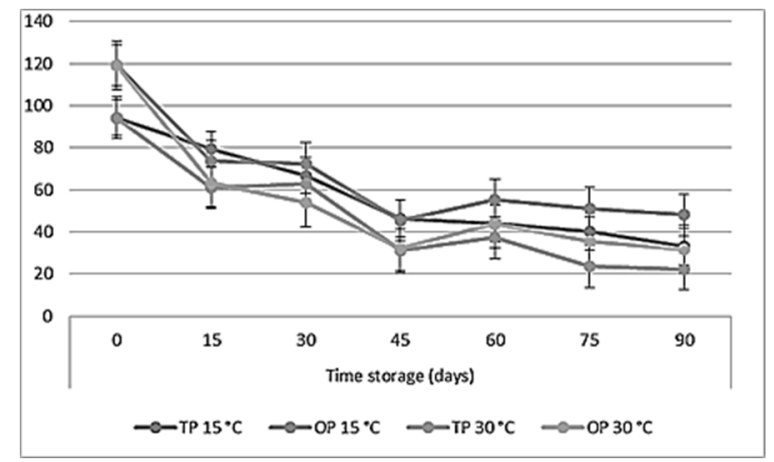

Figure 2. $\mathrm{DPPH}^{\circ}$ in orange jam during storage at different temperatures. 


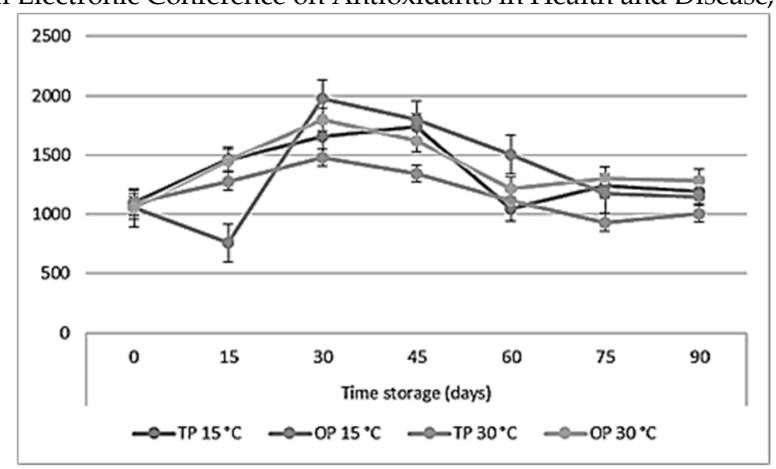

Figure 3. $\mathrm{ABTS}^{\circ}$ in orange jam during storage at different temperatures.

\section{Discussion}

Jams $\mathrm{pH}$ did not differ from each other $(p>0.01)$, which guarantees the stability of the product [10].

The addition of OP increased TA and TSS $(p<0.01)$. The highest TSS values detected for added samples(OP) could be linked to highest amount of pectina of orange peel. As previous studies reported [11], the increase of TSS depends on the formation of hydrogen bridges between sugars and citric and on the degradation of sucrose in glucose and fructose.

In addition, the formation of acids resulting to degradation of polysaccharides, the oxidation of reducing sugars and also the degradation of pectic and uronic acid could determine the increase of titrable acidity $[4,12]$. It was observed that the addition of orange peels to the jam resulted in an increase in antioxidant activity. This is due to the fact that the peel is rich in essential oil which contains bioactive molecules. Similar results were observed in fruit peel added jamelao [13].

Nevrethless, all samples showed an antioxidant activity in a concentration-dependent manner. Storage time and temperature affected the content of bioactive compounds as well as the antioxidant activity. Literature data reported that the decrease of bioactive compounds over time is due to odidation and polymerisation reactions. At the same time, the changes in antioxidant activity may be caused by a degradation or chemical alteration of product during storage [14]. the obtained results confirmed that the addition of OP improved the nutritional profile of orange jam. Furthermore, bioactive substances such as ascorbic acid, carotenoids, and phenolic compounds have antioxidant activity, adding potential functional properties to the product.

\section{Conclusions}

In this work, the orange peel was added to an orange jam. Product stability, and the antioxidant effect on storage time were investigated. The enriched samples (OP) show a slow decrease of all examined parameters. In fact, the addition of orange peel to jam slow down the oxidation. The obtained data show that the addition of orange peels is a valid alternative to pectin. Furthermore, the by-products of citrus fruits can be used as nutraceutical resources.

Author Contributions: V.S. carried out the overall project design experimental work, M.R.L., R.R., R.T., and M.L. analysed results and wrote the manuscript. M.L. and R.R. assisted with experimental work. M.P., R.T., M.R.L. and V.S conceptualized aspects of the project and assisted with reviewing and editing the manuscript. All authors read and agree to the published version of the manuscript.

Conflicts of Interest: The authors declare no conflict of interest.

\section{Abbreviations}

TP traditional pectin

OP orange peel

TA Titratable acidity

TSS Total solid soluble 
The 1st International Electronic Conference on Antioxidants in Health and Disease, 1-15 December 2020

DPPH 2,2-Diphenyl-1-picrylhydrazyl

ABTS 2,2'-azinobis (3-ethylbenzothiazoline-6-sulfonic acid) diammonium salt

\section{References}

1. Diomi Mamma, D.; Christakopoulos, P. Biotransformation of Citrus By-Products into Value Added Products. Waste Biomass Valori. 2014, 5, 529-549.

2. Sicari, V.; Pellicanò, T.M.; Giuffrè, A.M.; Zappia, C.; Capocasale, M. Bioactive compounds and antioxidant activity of citrus juices produced from varieties cultivated in Calabria. Food Meas. 2016, 10, 773-780. doi:10.1007/s11694-016-9362-8.

3. Mirabella, N.; Castellani, V.; Sala, S. Current options for the valorization of food manufacturing waste: A review. J.Clean. Prod. 2014, 65, 28-41.

4. Wang, Y.-C.; Chuang, Y.-C.; Hsu, H.-W. The Flavonoid, Carotenoid and Pectin Content in Peels of Citrus Cultivated in Taiwan. Food Chem. 2008, 106, 277-284.

5. Rafiq, S.; Kaul, R.; Sofi, S.A.; Bashir, N.; Nazir, F.; Nayik, G.A. Citrus peel as a source of functional ingredient: A review. J. Saudi Soc. Agric. Sci. 2018, 17, 351-358. doi:10.1016/j.jssas.2016.07.006.

6. Singleton, V.L.; Orthofer, R.; Lamanuela-Raventòs, Rm. 1999. Analysis of total phenols and other oxidation substrates and antioxidants by means of folin-ciocalteu reagent. Meth. Enzymol. 1999, 299C, 152-178.

7. Rodriguez-Amaya, D.B.; Kimura, M. Handbook for Carotenoid Analysis; International Food Policy Research Institute (IFPRI) and International Center for Tropical Agriculture (CIAT): Washington, DC, USA, 2004.

8. Brand-Williams, W.; Cuvelier, M.; Berset, E.C. Use of a free radical method to evaluate antioxidant activity. LWT-Food Sci. Technol. 1995, 28, 25-30.

9. Re, R.; Pellegrini, N.; Proteggente, A.; Pannala, A.; Yang, M.; Rice-Evans, C. 1999. Antioxidant activity applying an improved ABTS radical cation decolarization assay. Free Radic. Biol. Med. 1999, 26, 1231-1237.

10. Touati, N.; Tarazona-Diaz, M.P.; Aguayo, E.; Louaileche, H. Effect of storage time and temperature on the physicochemical and sensory of commercial apricot jam. Food Chem. 2014, 145, $23-27$.

11. Teixeira, F.; Santos, B.A.; Nunes, G.; Soares, J.M.; Amaral, L.A.; Souza, G.H.O.; Resende, J.T.V.; Menegassi, B.; Rafacho, B.P.M.; Schwarz, K.; et al. Addition of Orange Peel in Orange Jam: Evaluation of Sensory, Physicochemical, and Nutritional Characteristics. Molecules 2020, 25, 1670.

12. Rashid, F.; Kausar, T.; Qureshi, T.M.; Hussain, S.; Nadeem, M.; Ainee, A.; Zahra, S.M. Physico-chemical and sensory properties of orange marmalade supplemented with aloe Vera powder. J. Agric. Res. 2014, 52, 561-568.

13. Kamiloglu, S.; Pasli, A.A.; Ozcelik, B.; Van Camp, J.; Capanoglu, E. Influence of different processing and storage conditions on in vitro bioaccessibility of polyphenols in black carrot jams and marmalades. Food Chem. 2015, 186, 74-82.

14. Tobal, T.M.; Rodrigues, L.V. Effect of storage on the bioactive compounds, nutritional composition and sensory acceptability of pitanga jams. Food Sci. Tech. 2019, 39, 581-587.

Publisher's Note: MDPI stays neutral with regard to jurisdictional claims in published maps and institutional affiliations.

(C) 2020 by the authors. Licensee MDPI, Basel, Switzerland. This article is an open access article distributed under the terms and conditions of the Creative Commons Attribution (CC BY) license (http://creativecommons.org/licenses/by/4.0/). 